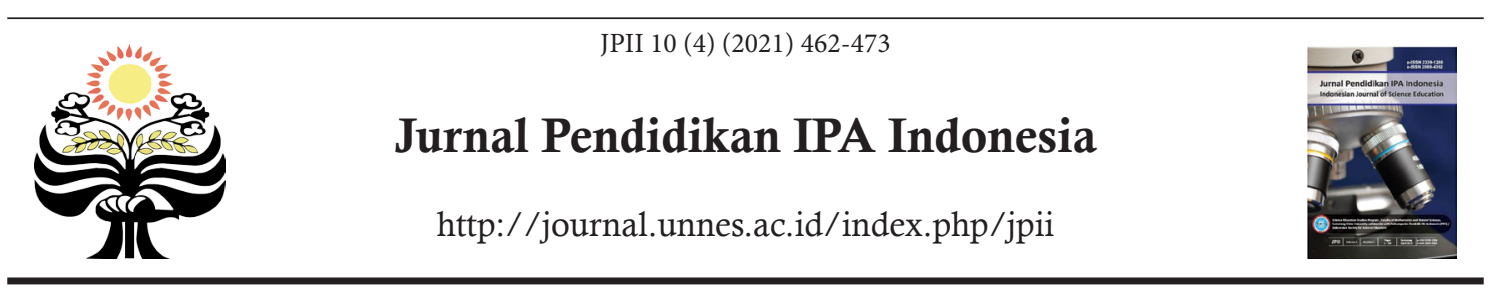

\title{
GAMIFICATION IN GENETICS: EFFECTS OF GAMIFIED INSTRUCTIONAL MATERIALS ON THE STEM STUDENTS' INTRINSIC MOTIVATION
}

\author{
A. A. Funa ${ }^{* 1,4}$, R. A. E. Gabay ${ }^{2}$ J. D. Ricafort ${ }^{3}$ \\ ${ }^{1,2}$ Department of Science Education, De La Salle University, Manila, Philippines \\ ${ }^{3}$ Sorsogon State University, Sorsogon, Philippines \\ ${ }^{4}$ Member, Social Science Division, National Research Council of the Philippines
}

DOI: 10.15294/jpii.v10i4.32143

Accepted: September 23 ${ }^{\text {rd }} 2021$. Approved: December 27 ${ }^{\text {th }}$ 2021. Published: December $31^{\text {st }} 2021$

\begin{abstract}
Gamification in education offers an innovative way of learning. However, some studies claim that, while it helps raise students' motivation, the kind of motivation is extrinsic and, so, intrinsic motivation declines with time. The researchers used the descriptive research design to describe the STEM students' intrinsic motivation along with the utilization of game elements in teaching genetics through a learning management system. The researchers collected quantitative data using the Intrinsic Motivation Inventory, which were analyzed through descriptive statistics and complemented with qualitative data from the students' journals and interviews. Overall, the students agreed $(\mathrm{M}=5.38, \mathrm{SD}=1.20)$ that gamification, despite being characterized as extrinsically motivating, had intrinsically motivated them. Its proper implementation helps students adapt to and overcome unfavorable behaviors towards competitiveness and emphasizes the role of teachers in facilitating learning. Time constraints, peer pressure, and distractions were noted; hence, more research is needed to address these challenges and determine the long-term effects of gamification.
\end{abstract}

(c) 2021 Science Education Study Program FMIPA UNNES Semarang

Keywords: gamification; gamified learning; self-determination theory; intrinsic motivation; STEM education

\section{INTRODUCTION}

Gamification is the use of game concepts in non-gaming contexts to offer consumers game-like, enjoyable experiences (Deterding et al., 2011; Hamari et al., 2014; Fleischmann \& Ariel, 2016; Huotari \& Hamari, 2016). Research studies have shown that gamification, when pedagogically applied in science education, can positively affect students' academic performance (Funa \& Ricafort, 2019a; Kalogiannakis et al., 2021). However, some research suggests that gamification in education is not intrinsically motivating and may reduce intrinsic motivation over time (Hanus \& Fox, 2015; Mekler et al., 2017). In this regard, this study aimed to investigate the effects

*Correspondence Address

E-mail: aaron_funa@dlsu.edu.ph of gamification on the intrinsic motivation of Science, Technology, Engineering, and Mathematics (STEM) students, particularly in learning genetics.

The twenty-first century learners are recognized to have been born in a world where technology is an important component of human life and incorporating it into their daily educational activities is essential. As technology improves, several sorts of games that generate the interest and motivation of students are being developed. This has given rise to many game components and elements, including points, badges, power cards, game mechanics, levels, and leaderboards, among others (Funa \& Ricafort, 2019b). Bringing education to the next level, technology has been integrated into a learning environment that incorporates gaming aspects in non-gaming contexts to support different activities and behaviors. 
On one hand, when utilized in education, both technology and games have good influence on students' psychological and behavioral aspects (Hamari et al., 2014) and can make learning more enjoyable (Fleischmann \& Ariel, 2016). These favorable results have increased the popularity of gamification and drawn attention to the educational community (Majuri et al., 2018). Digital-based games, for example, may reduce cognitive load, enhance learning outcomes, and raise student enthusiasm (Hwang et al., 2013; Sánchez-Martín, 2017; Yildirim, 2017; Funa \& Ricafort, 2019a). Even though the application of gamification in education has a beneficial impact on students' learning experiences, additional research studies are required to facilitate systematic reviews such as meta-analysis and meta-synthesis (Dicheva et al., 2015). On the other hand, the effects of gamification on students' motivation, satisfaction, and empowerment are not always positive. Some studies reported declining outcomes when they used gamification as a pedagogy over time, linking it with novelty expiry and decreased excitement (Hanus \& Fox, 2015; Mekler et al., 2017). Hence, studies have indicated that additional research into the varied situations under which gamification is beneficial for different students is imperative.

Gamification in education is commonly connected with external motivation because of the use of external rewards such as points, badges, and leader boards (Funa \& Ricafort, 2019b; Gilyazova \& Zamoshchanskii, 2020). This kind of motivation fosters competitiveness, which has several adverse effects on students' academic achievement (Deci et al., 1981). However, while both extrinsic and intrinsic motivation may result in increased students' performance, only intrinsic motivation is directly associated with considerably improved mental health, creativity, learning outcomes, and sustained involvement in an activity (Ryan \& Deci, 2000; Cerasoli, 2014). In this regard, the present researchers examined the effects of gamification on students' intrinsic motivation. Intrinsic motivation is a type of motivation that arises when a person wants to do something but receives no reward other than the act itself (Deci, 1971). It is divided into several factors, including interest/enjoyment, perceived competence, effort/importance, pressure/tension, perceived choice, value/usefulness, and relatedness (Ryan, 1982; McAuley et al., 1989). By examining the effects of gamification on intrinsic motivation, researchers may get a better understanding of how gamification motivates students in ways other than rewards and punishments.
This study is important to inform on the use of gamification as a pedagogical approach in science education, to better understand it, and to add to the existing studies to facilitate literature reviews and analyses. The purpose of this study was to describe the effects of gamification on the intrinsic motivation of STEM students. Specifically, the researchers answered the question: what is the level of the intrinsic motivation of STEM students after using the developed gamified instructional materials in genetics (Funa \& Ricafort, 2019a, 2019b) in terms of (a) interest/ enjoyment, (b) perceived competence, (c) effort/ importance, (d) pressure/tension, (e) perceived choice, (f) value/usefulness, and (g) relatedness?

\section{METHODS}

To investigate the effects of gamification on students' intrinsic motivation, the researchers employed the descriptive research design in which observational and survey research methods were used to obtain data from students. This design is a fundamental way of examining issues in their present condition (Leedy \& Ormrod, 2001; Williams, 2007). A series of interviews were conducted to substantiate the students' responses and entries in their journals. Interview is important to gather extensive information and infer meaningful statistical results (Creswell \& Creswell, 2018).

In determining the participants, the researchers used the purposive total enumeration sampling technique. It is used to deliver critical information that are not available via other samples (Taherdoost, 2016; Maxwell, 2020). In this technique, the entire population of grade 12 STEM students in one of the public schools in the Philippines was chosen as participants. There were 41 Filipino grade 12 STEM students coming from one intact class who consented to participate in this study. These students shared the same experiences and characteristics as they belonged in one intact class in senior high school and even when they were in their junior high school level.

In this study, two instruments were used: the Intrinsic Motivation Inventory (IMI) (https:/ / gih.instructure.com / files / 2040 / download?download_frd=1), and the students' reflective journals. The IMI is a multidimensional, 45-item, 7-point Likert-scale instrument (1not at all true, 4-somewhat true, and 7-very true) that was adopted from earlier studies on intrinsic motivation (Intrinsic Motivation Inventory, n.d.; Ryan et al., 1983; McAuley et al., 1989). It allowed the researchers to assess post-experimental intrinsic motivation. The validity of this instru- 
ment was determined to be high. For instance, the internal consistency of the four subscales, had the following alpha estimates: $\alpha=.78$ for interest/enjoyment, $\alpha=.80$ for perceived competence, $\alpha=.84$ for effort, and $\alpha=.68$ for pressure/ tension. The overall internal consistency had a Cronbach's alpha estimate of .85 (McAuley, et al., 1989). Despite the validity of this instrument, it was still validated by the evaluators, consisting of master teachers in biology, prior to administration. It was administered at the end of the entire learning sessions in genetics to assess the intrinsic motivation of students. The other source of data was the students' reflective journals. Entries in the reflective journals were essential to substantiate the students' responses to the IMI and facilitate the creation of interview questions.

To follow ethical procedures, the researchers sought permission from the rightful authorities to have the study conducted at their institution. As soon as the permission was granted, the researchers coordinated with the class adviser and began the orientation and filling out of consent forms by students. Only the data of those students who were given consent, were analyzed during and after the implementation of the developed gamified instructional materials (GIM) in genetics - a set of gamified modules adopted from the study of Funa \& Ricafort (2019a; 2019b). The implementation phase was completed over a period of 750 minutes (15 days), utilizing the provided GIM in genetics and Schoology as the learning management system. The GIM includes seven topics: 1) analysis of pedigrees; 2) sex linkage and recombination; 3) modification of Mendel's classic ratios; 4) the molecular structure of DNA, RNA, and proteins; 5) DNA replication and protein synthesis; 6) genetic engineering; and 7) discussion of recombinant DNA applications.

Aside from the time allowed for classroom teaching, there was also time allotted for interviews and journal evaluations during the students' vacant periods, which generally occurred following the sessions. Journal logs and activities that students could complete with some or no supervision were accomplished in the library or at home. Completing these tasks is tantamount to the acquisition of badges and the accumulation of points. After all the lessons had been carried out, they were tasked with finalizing their journal logs and filling out the IMI to evaluate the effects of gamification on their intrinsic motivation. The researchers employed descriptive statistics, including the weighted mean, to examine the post-experimental evaluation of students' intrinsic motivation using the IMI. The computed weighted mean was evaluated using the following scales: 6.6-7.0 (very true), 5.6-6.5 (true), 4.6-5.5 (somewhat true), 2.6-3.5 (slightly not true), 1.6-2.5 (not true), and 1.0-1.5 (not at all true). Responses from students' journals and interviews were utilized to substantiate the answers in the IMI.

\section{RESULTS AND DISCUSSION}

The discussion of the results was patterned on the factors involved in the IMI, namely: (a) interest/enjoyment, (b) perceived competence, (c) effort/importance, (d) pressure/tension, (e) perceived choice, (f) value/usefulness, and (g) relatedness. Items with an $(\mathrm{R})$ or reversed symbol are negative items that were scored backward to assist the researchers in determining the dependability of students' answers and to prevent "straight line" answering. Hence, rescoring was necessary in order to fit these items with the positive items; 7 was the lowest and 1 was the highest, wherein 7 was replaced by 1 and 1 was replaced by 7 . By changing the scores of items with the $(R)$, the negative items could be treated as normal for better analysis. All reversed scores were changed to positive in the succeeding tables and discussion.

The term interest/enjoyment refers to the satisfaction that students feel when participating in gamification. According to the overall result of Interest/Enjoyment $(\mathrm{M}=5.66, \mathrm{SD}=1.07)$, as shown in table 1 .

Table 1. Level of Intrinsic Motivation along Interest/Enjoyment

\begin{tabular}{lccc}
\hline \multicolumn{1}{c}{ Items } & $\begin{array}{c}\text { Weighted } \\
\text { Mean }\end{array}$ & SD & Interpretation \\
\hline I would describe this game as very interesting. & 6.07 & 0.82 & SA \\
This game was fun to do. & 5.95 & 0.95 & SA \\
I enjoyed doing this game very much. & 5.85 & 0.85 & SA \\
This game did not hold my attention at all. (R) & 5.85 & 1.20 & SA \\
I thought this game was quite enjoyable. & 5.63 & 0.89 & SA \\
While doing this game, I was thinking about how much I enjoyed it. & 5.63 & 0.97 & SA \\
I thought this was a boring game. (R) & 4.63 & 1.84 & A \\
\multicolumn{1}{c}{ Average } & 5.66 & 1.07 & SA \\
Note: (R) - Reversed; SA - Strongly Agree; A - Agree & & &
\end{tabular}


The participants strongly agreed that gamification in education piqued their interest and that they appreciated the activities associated with its implementation. In the students' journals, the innovative way of presenting the lessons captured their interest quickly ("The lesson was presented in a unique way that it captured my interest quickly" -Student 38). The new method of delivering the lesson put them under a lot of pressure, but in the end, students were able to adapt so well that it became acceptable and enjoyable ("It was quite pressuring but in the long run, I learned to enjoy it." -Student 38). Furthermore, among the features that made the game exciting were the competitiveness and the random calling of names during recitations ("I love the excitement on whom to be called during recitations. Also, the competition amongst us during every activity adds up to the spice of the game." -Student 34).

Based on the entries of students 38 and 34 , pressure and competition made the game exciting and enjoyable. These results are in consonance with the findings of Deci et al. (1981) and Cagiltay et al. (2015) that competition may extrinsically motivate students. As a consequence, when the teacher presented the game to students, they prioritized competition and looked at every activity as an opportunity for winning rather than learning; hence, with this kind of motivation, the intrinsic motivation of students was likely to decrease (Hanus \& Fox, 2015; Mekler et al., 2017). However, competitiveness in a gamified learning environment, according to Glover (2013), has a beneficial effect on students' conduct and helps them overcome unfavorable attitudes towards competition. As a result, during the implementation of the study, although winning the game was important, the teacher was always present to facilitate and remind the students that it was learning that should matter most. Another factor that made the game interesting was mentioned by Student 16 in the journal entry that pertains to the desire for badges, points, and power cards. The three consecutive journal entries of student 16 showed that the game elements like badges, points, and power cards could elicit their interest. This observation agrees with the results obtained by Hamari et al. (2014).

Journal entry 1: "Before the game, I tried to review the lesson so I could recite when the game master called me. The game was energetic, fun, and enjoyable. During the game, I rushed with adrenaline to answer questions to earn badges or points, but the master did not call me again." Journal entry 2: "Before the game or lesson, I felt a little bit nervous. I did not read or review the said lesson. And there was a group activity. Our team won. We were having fun, all were noisy. And we won badges thanks to our team leader, the game was easy, it was just a colorblind test." Journal entry 3: "Before the game, I was calm. And a group name occurred, I was pressured a little bit because I do not know a lot about the game. But I also enjoyed it. I used two of my power cards. After the game, the enjoyment was still there."

Collectively, the responses of Student 16 demonstrate that gamification motivated them to prepare ahead of time, to actively participate during activities and recitations, and to win badges and points, both individually and as a group. According to the interview with the students, the pressure, excitement, and adrenaline rush made the game more fun. However, sometimes, disappointment may be felt when they fail to get any badges or points. The journal entry 2 by Student 16 shows that they felt lucky that day because, although their preparation was little, their team won and earned badges. Consequently, the feeling of disappointment on the first day (journal entry 1) was relieved by the victorious feeling on the next day. Examining journal entry 3, Student 16 adapted and enjoyed playing the game and doing the gamified activities.

These three consecutive journal entries of student 16 show how a student may react to gamification. At first, pressure and excitement could be felt when newly introduced to this kind of pedagogical approach. Sadness could also be felt as a consequence of failed expectations. Based on the interviews with the students, these various emotions (e.g., nervousness, excitement, pleasure, etc.) are essential elements that make the lesson more enjoyable. The capability of the students to adapt to a stressful environment makes gamification in education fun and exciting.

The abovementioned scenario could be better explained by the constructivism theory of Piaget (1929). At first, the students assimilate new information, which makes them feel pressured and excited. Then, when a certain expectation was not met, they felt sadness. However, by accommodating these new experiences, they learned and adapted. In this case, learning how to play the game makes gamification more fun and enjoyable. This may explain why grade 12 STEM students managed the situation and strongly agreed that gamification could elicit their interest and enjoyment despite the pressure and competition. 
Perceived competence is the feeling of students' satisfaction with their performance during gamification. As shown in Table 2, the highest score was given to the statement, "After working at this game for a while, I felt pretty competent." While the lowest score was given to the statement, "I was pretty skilled at this game." These findings imply that students may doubt their abilities at the start of gamification. However, they have adapted and have become acclimated to it over time, and as a result, they feel more capable and competent. This phenomenon may be explained by Piaget's constructivism theory, as stated previously.

Table 2. Level of Intrinsic Motivation along Perceived Competence

\begin{tabular}{lccc}
\hline \multicolumn{1}{c}{ Items } & $\begin{array}{c}\text { Weighted } \\
\text { Mean }\end{array}$ & SD & Interpretation \\
\hline After working at this game for a while, I felt pretty competent. & 4.98 & 1.33 & $\mathrm{~A}$ \\
This was a game that I could not do very well. (R) & 4.93 & 1.56 & $\mathrm{~A}$ \\
I am satisfied with my performance at this game. & 4.63 & 1.34 & $\mathrm{~A}$ \\
I think I am pretty good at this game. & 4.54 & 1.10 & $\mathrm{~A}$ \\
I think I did pretty well at this game, compared to other students. & 4.46 & 0.87 & NAND \\
I was pretty skilled at this game. & 4.12 & 1.12 & NAND \\
\multicolumn{1}{c}{ Average } & 4.61 & 1.22 & A \\
\hline
\end{tabular}

Student 21 , belonging to the top students in their class, mentioned that playing the game was easy ("If the rest of the lessons are gonna be this easy, then I would not worry about my competency. I did fine and I'm sure it's great" -Student 21). In between activities and lessons, because of the excitement of playing the games, Student 21 became more confident until realizing that too much attention and effort were being put into the game and that the competition and toning down is necessary ("I might be doing too much. Because my mind perceives this as a kind of game, I was probably overdoing my actions and being over-competent. Also, I am starting to take into consideration the fact that I need to tone it down a bit." -Student 21).

To investigate further, the researchers interviewed student 21 , asking about the decision to tone down the momentum invested in the game. Student 21 realized that winning the game should be prioritized second only to learning, although the game motivated them to learn. This is in contrast to the findings of Deci et al. (1981), claiming that gamification makes students focus on winning rather than learning. This phenomenon may be attributed to the teacher's abovementioned intervention, in which it was clearly conveyed to the students that, although winning the game was essential, learning should be their primary goal. Thus, these findings indicate that the role of teachers in facilitating learning is essential to the effectiveness of designing, planning, and implementing gamification in relation to students' intrinsic motivation.
To make comparisons, the researchers examined the journal entries belonging to a student who was not as confident as Student 21. According to the journal entry, Student 33 was called for a recitation but did not answer and let the chance be grabbed by others. As a result, sadness was exhibited, and losing hope in learning biology was felt ("I am not satisfied with my experience because I let the chance of having the energy booster badge spill away. Sad to say but I feel like I'm becoming more and more of a slow learner in biology as the day passes by. I am also slowly losing the will to fight harder." -Student 33). However, in the succeeding lessons, Student 33 was called again for recitation ("Even if I did not explain the answer for the specific question, I felt satisfied. The chance that I let slip away was returned to me because I get to answer a correct one" -Student 33). This reaction indicates that happiness was felt, and grief was eased. These emotions are similar to the interest/enjoyment concept, in that if expectations are not satisfied, a sense of unhappiness may arise as a result, yet the sensation of sadness may open the door to adapt, improve, and advance. These results are consistent with the findings of Glover (2013) that competition improves students' behavior and helps them overcome negative views towards it.

Gamification has been more exciting as a result of competitiveness (Höllig et al., 2020; Danelid \& Fältman, 2021). However, when using games, teachers should be conscious of their students' sentiments in order to make an appropriate intervention on how to prevent students' dissatis- 
faction as a result of competition. Social comparison is heightened by posting students' names (even pseudonyms) to leaderboards (Christy \& Fox, 2014). Teachers may double their attention to low-performing students despite giving attention to achievers in the class. Giving these lowperforming students opportunities to engage and feel as though they could answer questions and participate in class helps them boost their confidence and interest in the lesson. Overall, the perceived competence garnered an average score of
$\mathrm{M}=4.61, \mathrm{SD}=1.22$, signifying that the students agreed that they were satisfied with their performance during the use of gamification in their class.

The term effort/importance refers to the energy expended by students in all of their activities. As demonstrated in Table 3, students firmly agreed that gamification was essential to them and that they put a lot of effort into playing while learning the lessons.

Table 3. Level of Intrinsic Motivation along Effort/Importance

\begin{tabular}{|c|c|c|c|}
\hline Items & $\begin{array}{c}\text { Weighted } \\
\text { Mean }\end{array}$ & SD & Interpretation \\
\hline It was important to me to do well at this game. & 6.34 & 0.73 & VSA \\
\hline I put a lot of effort into this. & 5.61 & 0.92 & SA \\
\hline I tried very hard on this game. & 5.59 & 1.07 & SA \\
\hline I did not try very hard to do well at this game. (R) & 5.29 & 1.49 & A \\
\hline I did not put much energy into this. (R) & 5.22 & 1.19 & A \\
\hline Average & 5.61 & 1.08 & SA \\
\hline
\end{tabular}

The notes in the journal logs showed that the students put in a lot of effort while playing the game. These efforts manifested in the form of prior reading and studying, which allowed them to respond during recitations and class activities. The following are the students' responses that support the results of the IMI: "For me, I need to make effort to this game in order to have better grades/points and earn badges. My goal is not to be on the leaderboard, but to survive and perform every task. I will do my best and give effort in every task." -Student 16; "Since we have to strive points to be able to be on the leaderboard, we put a lot of effort in every activity starting from recitation. So advance study and research is a must." -Student 9; "All of the team leaders and their members were very aggressive and had exerted much effort on this lesson." -Student 26. According to their journal logs, there were numerous reasons why they worked so hard in the game. These reasons include getting higher grades, leveling up, earning badges and points, being on the leaderboard, and dealing with peer pressure.

In an interview with student 26 , importance was given to each lesson. Aside from considerations such as gaining points and dealing with social pressure, an effort was expended because playing the game was enjoyable and interesting. Furthermore, the students recognized and appreciated the teacher's efforts in carrying out the lectures by utilizing game components. In return, they valued the lesson more. Gamification is predicted to enhance effort exertion among students (Hanus \& Fox, 2015). In this regard, teachers are encouraged to contribute and demonstrate their full ability to gamify instructions.

The fourth component of IMI pertains to students' feelings of pressure and stress. Students, as indicated in Table 4, agreed that they were tensed and anxious during class. These findings indicate that, despite feeling uncomfortable while playing the game, some students were able to keep their anxiety under control. According to Hanus \& Fox (2015), the impact of pressure may differ from person to person, resulting in either good or bad results.

Examining the students' journal logs reveals that the pressure and tension they felt throughout the class caused them anxiety. Although they were all aware that the game was only a strategy for learning and that they should regard it as a friendly game, they could not escape the pressure. Student 34 did not anticipate the pressure that drove everyone to complete the game; nonetheless, the stress made the game more thrilling and enjoyable ("The tension between the group is too much, it puts on a different and new flame on the game. The eagerness of everyone to win or rank up to the game is way above my expectations." -Student 34). 
Table 4. Level of Intrinsic Motivation along Pressure/Tension

\begin{tabular}{lccc}
\hline \multicolumn{1}{c}{ Items } & Weighted Mean & SD & Interpretation \\
\hline I felt very tensed while doing this game. & 5.32 & 1.47 & $\mathrm{~A}$ \\
I did not feel nervous at all while doing this. (R) & 5.29 & 1.58 & $\mathrm{~A}$ \\
I was very relaxed in doing these. (R) & 5.02 & 1.41 & $\mathrm{~A}$ \\
I felt pressured while doing these. & 4.93 & 1.98 & $\mathrm{~A}$ \\
I was anxious while working on this task. & 4.46 & 1.50 & NAND \\
\multicolumn{1}{c}{ Average } & 5.00 & 1.59 & $\mathrm{~A}$ \\
\hline Note: (R) - Reversed; A - Agree; NAND - Neither Agree nor Disagree & &
\end{tabular}

Several causes for the felt pressure/tension in the classroom were discovered during the interview. Time constraints, peer pressure, and competitive peers were among these issues. These results are parallel with the findings of Ahmad et al. (2020), in which the positive results obtained by computer science students may be attributed to group sizes and types of quizzes. Additionally, as previously stated, students' adaptability to gamification is tied to constructivism. Time constraints post a challenge to the constructivist approach as applied in biology subjects (Funa \& Talaue, 2021).

During an interview, student 39 revealed that the pressure added to the pleasure of the game. However, the student furthered that it is ex- hausting to strive to win when other students are similarly competitive. Hence, pushing one's limitations is important. When compared with conventional or traditional methods of teaching, student 39 still favored the use of game components, despite the fact that there was a lot of pressure.

The fifth component of the IMI is the perceived choice, which refers to students' choices during lesson implementation. As demonstrated in Table 5, students' perspectives differ depending on whether they chose to play the game or were forced to. The total score, on the other hand, indicates that grade 12 STEM students opted to join and play the game because they wanted to, rather than because they were forced to.

Table 5. Level of Intrinsic Motivation along Perceived Choice

\begin{tabular}{lccc}
\hline \multicolumn{1}{c}{ Items } & $\begin{array}{c}\text { Weighted } \\
\text { Mean }\end{array}$ & SD & Interpretation \\
\hline I did this game because I wanted to. & 5.68 & 1.27 & SA \\
I felt like it was not my own choice to do this game. (R) & 5.51 & 1.36 & SA \\
I did this game because I had no choice. (R) & 5.27 & 1.58 & $\mathrm{~A}$ \\
I did not really have a choice about doing this game. (R) & 5.24 & 1.51 & $\mathrm{~A}$ \\
I believe I had some choice about doing this game. & 5.22 & 1.44 & $\mathrm{~A}$ \\
I felt like I had to do this. (R) & 3.17 & 1.79 & $\mathrm{D}$ \\
I did this game because I had to. (R) & 3.07 & 1.66 & $\mathrm{D}$ \\
$\quad$ Average & 4.74 & 1.52 & $\mathrm{~A}$ \\
\hline
\end{tabular}

Note: (R) - Reversed; SA - Strongly Agree; A - Agree; D - Disagree

Students were told at the start of the study, when the researchers were looking for participants, that they could choose to play the game or not. This was particularly important in terms of research ethics, as it allowed participants to choose whether or not to engage in the present study. Students who did not want to engage in the activities could still join the class, but their data would not be utilized for the study. Following the orientation, all grade 12 STEM students chose to participate in the research and game. Even though the teacher gave the students freedom to join the study, they participated because they perceived that it was essential to get high grades ("We don't really have a choice but to be part of this game even if we don't want to. But it is still our choice if we want to let ourselves be left behind or let ourselves enjoy and be more active during the game." -Student 29). However, this thought was not true for all. Other students joined not because they feared failing the subject, but because they enjoyed the game as well as the topic. This is elaborated in the journal entries of three students, as presented below: 
"As usual, it was definitely a hundred percent my choice to participate in this. The thrill of this game is always compelling me to do as much as I can, pushing me to do better." -Student 21; "I chose to have fun instead of just sitting down. Even though I didn't earn points, or our group didn't earn points, I still had fun. It was a hard day, but a lesson learned." -Student 16; "It was definitely my choice to participate and cooperate during the topic. I chose to participate because the topic is very interesting and fun." -Student 14

The journal logs of students 21,16 , and 14 demonstrate that students chose to engage in the activities not just for the grades but also for the following: the pleasant experience of playing the game, encouraging game elements, and interest in the topic. These results are consistent with the findings of Pechenkina et al. (2017), wherein gamification captures the interest of students. Further, these findings suggest that students participate in various activities for a variety of reasons. Thus, delivering courses in diverse and innovative ways encourages students' involvement.

The sixth component of IMI is value/ usefulness, which pertains to the students' perceptions of the importance of each activity that they do. As shown in Table 6, students highly felt that using gamification in genetics was useful and might be beneficial to them. This was demonstrated by their participation in activities that occasionally generated noise, as described previously.

Table 6. Level of Intrinsic Motivation along Value/Usefulness

\begin{tabular}{lccc}
\hline \multicolumn{1}{c}{ Items } & $\begin{array}{c}\text { Weighted } \\
\text { Mean }\end{array}$ & SD & Interpretation \\
\hline I think that doing this game is useful & 6.56 & 0.59 & VSA \\
I think doing this game could help me & 6.56 & 0.55 & VSA \\
I think this is an important game & 6.46 & 0.60 & SA \\
I believe doing this game could be beneficial to me. & 6.44 & 0.55 & SA \\
I think this is important to do & 6.32 & 0.72 & SA \\
I believe this game could be of some value to me. & 6.17 & 0.74 & SA \\
I would be willing to do this again because it has & 6.12 & 0.93 & SA \\
some value to me. & & & \\
& 6.38 & 0.67 & SA \\
\hline
\end{tabular}

Note: (R) - Reversed; VSA - Very Strongly Agree; SA - Strongly Agree

According to students' journal entries, the game was beneficial because it stimulated students to study more, participate in activities, concentrate on discussions, increase self-esteem, promote critical thinking and creativity, and make the class more enjoyable. The following are the students' journal entries, verbatim: "As the game lasts, I can see much of its usefulness, especially if I have more useful power cards. I also notice that it could help shy students to at least improve their self-esteem during the recitation in class." -Student 27; "The game was so fun and useful because it helps us to enjoy every activity and every discussion for us to gain more knowledge." -Student 2 . These responses may be attributed to why students chose to participate and emphasize the significance of the game. Further, they were certain that the games they were playing during the class would benefit them in the future.
During an interview, the students mentioned that, while the game is exciting and entertaining, it is also taxing. This is in contrast with the findings of Saputra et al. (2021) that gamification overcomes fatigue by regulating feelings and stabilizing emotions. As a result, the current researchers recommend resting periods in between activities. Teachers may administer the games intermittently, which implies that there may be meetings where there is no gamification involved. This way, fatigue may be avoided while excitement is maintained.

Relatedness is the last part of IMI that pertains to the belongingness of the whole class as felt by the students. This is the feeling of involvement manifested by the acts of participation, cooperation, and camaraderie. Table 7 shows the students' ratings of relatedness. 
Table 7. Level of Intrinsic Motivation along with Relatedness

\begin{tabular}{|c|c|c|c|}
\hline Items & $\begin{array}{c}\text { Weighted } \\
\text { Mean }\end{array}$ & SD & Interpretation \\
\hline $\begin{array}{l}\text { It is likely that my classmates and I could become friends if we } \\
\text { interacted a lot. }\end{array}$ & 6.12 & 0.75 & SA \\
\hline I really doubt that my classmates and I would ever be friends. (R) & 6.02 & 1.13 & SA \\
\hline I would like a chance to interact with the class more often. & 5.88 & 1.10 & SA \\
\hline I do not feel like I could really trust my classmates. (R) & 5.78 & 1.53 & SA \\
\hline I feel close to my classmates. & 5.63 & 1.04 & SA \\
\hline $\begin{array}{l}\text { I would really prefer not to interact with my classmates in the } \\
\text { future. (R) }\end{array}$ & 5.41 & 1.99 & A \\
\hline I felt really distant from my classmates. (R) & 5.27 & 1.36 & A \\
\hline I felt like I could really trust my classmates. & 5.07 & 1.31 & A \\
\hline Average & 5.65 & 1.28 & SA \\
\hline
\end{tabular}

Note: (R) - Reversed; SA - Strongly Agree; A - Agree

As shown in Table 7, students strongly agreed that employing gamification in the teaching and learning process strengthened their bonds. On the other hand, as indicated in the last item of Table 7, they had different perspectives on trust, suggesting that while students thought that more interaction led to friendship, they could not fully trust one another. The students' sense of competition may have contributed to this result ("The competition is very intense. The players argue with one another and fight for their stand but learn how to accept others' ideas in the end. The interaction between the players is there, especially during recitation and group activities. Friends are still friends before and after the game and especially during the discussion." -Student 29).

According to the journal post of Student 29 , there was a strong competition among individuals and among groups during the game. Individuals and groups argued and fought, but after each session, they learned to accept each other's points of view and beliefs. The conflicts were typically exchanges of facts, perceptions, and knowledge that allowed them to add to and rectify their earlier concepts. Furthermore, the friendship remained after the game, implying that there was good and constructive interaction amongst students, which was heightened by the introduction of game components. In addition to the journal entry of Student 29, below are the entries of Students 4, 21, and 12: "I cooperated with my group well, so I can say I somehow relate or belong to them. I've done my part with or in the group and I'd be happy to do more. I was able to help my groupmates, even though I'm not good at that topic." -Student 4; "I felt like I was a valuable member of the team, each one with his/her purpose and contributions to the group. Everyone in the group was on the same page, so it was super easy to coordinate with everyone." -Student 21; "For the relatedness, I felt like we are players in a game online that we should help one another or work alone for the badges. I realized that I belong to a family like a class since we enjoyed a lot during the activity." -Student 12.

These responses of the students support the notion that gamification in education allows students to connect and form positive relationships with one another. These findings are in congruence with the findings of Gulinna \& Lee (2020), that the students felt a sense of belongingness with their group during a gameful experience. Students experienced their worth as members and a sense of accomplishment whenever they assisted their groupmates in earning points. In addition, these responses demonstrate that through student engagement and teamwork, they may overcome any difficulties posed by the game master, making the task easier to accomplish. As a result of gamification, students were able to establish a strong bond, wherein they characterized it as "family." Consequently, the road to understanding genetics became easier and more enjoyable for them.

Table 8 shows the overall average of the Post-Experimental Intrinsic Motivation Inventory in relation to gamification in genetics. The total IMI result had $\mathrm{M}=5.38, \mathrm{SD}=1.20$, indicating that the use of gamification in teaching genetics has intrinsically motivated grade 12 STEM students. This is consistent with the findings of $\mathrm{Ha}-$ mari et al. (2014), Fleischmann \& Ariel (2016), and Hwang et al. (2013), whom all pointed out that gamification is intrinsically motivating. 
Table 8. Post-Experimental IMI Results in Relation to Gamification in Genetics ( $N=41$ )

\begin{tabular}{lccc}
\hline \multicolumn{1}{c}{ Items } & Weighted Mean & SD & Interpretation \\
\hline VI. Value/Usefulness & 6.38 & 0.67 & SA \\
I. Interest/Enjoyment & 5.66 & 1.07 & SA \\
VII. Relatedness & 5.65 & 1.28 & SA \\
III. Effort/Importance & 5.61 & 1.08 & SA \\
IV. Pressure/Tension & 5.00 & 1.59 & $\mathrm{~A}$ \\
V. Perceived Choice & 4.74 & 1.52 & $\mathrm{~A}$ \\
II. Perceived Competence & 4.61 & 1.22 & $\mathrm{~A}$ \\
\multicolumn{1}{c}{ Average } & 5.38 & 1.20 & $\mathrm{~A}$ \\
\hline
\end{tabular}

Note: SA - Strongly Agree; A - Agree

These results are in contrast with Mekler et al. (2017) and Hanus \& Fox (2015) that gamification is not intrinsically motivating and that the inclusion of game features may diminish intrinsic motivation over time. This might be attributed to the nature of gamification and game aspects that are extrinsically motivating (Deci et al., 1981; Cagiltay et al., 2015). According to Markopoulos et al. (2015), to ensure intrinsic motivation in gamification, proper planning is required. Thus, more research on gamification and intrinsic motivation, with a particular emphasis on assuring the existence of intrinsic motivation, is advised to support the findings of this study. Nevertheless, the results and findings of this study are imperative to inform on gamification in education.

\section{CONCLUSION}

Several studies hold opposing opinions on the usefulness of gamification in pedagogical teaching and learning processes. According to the findings of this study, students were both excited and under pressure at the start of the gamified lesson. During implementation, they progressively adjusted to the newly adopted instructional method. Students' feelings, however, differed. Some were overjoyed because they were winning the games, and some were disappointed with their performances. Nevertheless, most of them adapted and had fun playing. These reactions and the gradual change of perceptions and feelings demonstrate the students' flexibility to adapt. Furthermore, these varied emotions are essential elements that made the game enjoyable and exciting. The following are the factors that catalyzed intrinsic motivation among students: student appreciation for the teacher's efforts in innovating activities; pleasant experiences of playing the game; encouraging game elements; interest in the topics; usefulness of the gained knowledge in the future; and a sense of belongingness and self-value. These elements piqued students' interest in the lesson and encouraged them to read and prepare ahead of time. Rewards and competition, however, are unavoidable components of the success of gamifying the lessons, despite being categorized as aspects of extrinsic motivation. As a result, the teacher's involvement and guidance in facilitating gamification are crucial. Time constraints, peer pressure, highly competitive classmates, and distractions were among the problems mentioned by the students in this study. To overcome these issues, the researchers recommend that teachers: establish a time limit for each activity; let students feel their presence by facilitating activities and encouraging them to participate; and guide students to avoid distractions by reminding them to focus on learning the lessons. The findings of this study are limited to participants from a single intact, homogeneous grade 12 STEM class and the competencies in genetics covered in their curriculum. The small number of participants limits the generalizability of the results. However, the results and findings of this study are significant to inform on the application of gamification as a pedagogical approach in education, particularly in science; add to the existing investigations that facilitate literature reviews and analyses; and be used for future studies on gamification and intrinsic motivation.

\section{REFERENCES}

Ahmad, A., Zeshan, F., Khan, M. S., Marriam, R., Ali, A., \& Samreen, A. (2020). The impact of gamification on learning outcomes of computer science majors. ACM Transactions on Computing Education (TOCE), 20(2), 1-25.

Cagiltay, N. E., Ozcelik, E., \& Ozcelik, N. S. (2015). The effect of competition on learning in games. Computers \& Education, 87, 35-41.

Cerasoli, C. P., Nicklin, J. M., \& Ford, M. T. (2014). Intrinsic motivation and extrinsic incentives jointly predict performance: A 40-year meta- 
analysis. Psychological Bulletin, 140(4), 980-1008.

Christy, K. R., \& Fox, J. (2014). Leaderboards in a virtual classroom: A test of stereotype threat and social comparison explanations for women's math performance. Computers \& Education, 78, 66-77.

Creswell, J. W., \& Creswell, J. D. (2018). Research design: Qualitative, quantitative, and mixed methods approaches. Thousand Oaks, CA: SAGE Publications.

Danelid, F., \& Fältman, E. (2021). Increasing Physical Activity with Gamification: Exploring Competitiveness as a Moderator for Leaderboard Effectiveness [Bachelor's dissertation, Umeå University].

Deci, E. L. (1971). Effects of externally mediated rewards on intrinsic motivation. Journal of Personality and Social Psychology, 18(1), 105-115.

Deci, E. L., Betley, G., Kahle, J., Abrams, L., \& Porac, J. (1981). When trying to win. Personality and Social Psychology Bulletin, 7(1), 79-83.

Deterding, S., Dixon, D., Khaled, R., \& Nacke, L. (2011). From game design elements to gamefulness. Proceedings of the 15th International Academic MindTrek Conference on Envisioning Future Media Environments - MindTrek 11.

Dicheva, D., Dichev, C., Agre, G., \& Angelova, G. (2015). Gamification in education: A systematic mapping study. Journal of Educational Technology \& Society, 18(3), 75-88.

Fleischman, K., \& Ariel, E. (2016). Gamification in science education: Gamifying learning of microscopic processes in the laboratory. Contemporary Educational Technology, 7(2), 138-159.

Funa, A., \& Ricafort, J. (2019a). Validation of gamified instructional materials in genetics for grade 12 STEM students. International Journal of Sciences: Basic and Applied Research, 47(2), 168-180.

Funa, A. A., \& Ricafort, J. D. (2019b). Developing gamified instructional materials in genetics for grade 12 STEM. Online Submission, 9(3), 2059720600.

Funa, A. A., \& Talaue, F. T. (2021). Constructivist learning amid the COVID-19 pandemic: Investigating students' perceptions of biology selflearning biology modules. International Journal of Learning, Teaching, and Educational Research, 20(3).

Gilyazova, O. S., \& Zamoshchanskii, I. I. (2020). On motivational tools of gamification in higher education: theoretical aspect. Perspectives of Science and Education, 45(3), 39-51.

Glover, I. (2013). Play as you learn: gamification as a technique for motivating learners. In Edmedia + innovate learning (pp. 1999-2008). Association for the Advancement of Computing in Education (AACE).

Gulinna, A., \& Lee, Y. (2020). College students' perceptions of pleasure in learning-Designing gameful gamification in education. Internation- al Journal on E-Learning, 19(2), 93-123.

Hamari, J., Koivisto, J., \& Sarsa, H. (2014). Does gamification work? -- A literature review of empirical studies on gamification. 2014 47th Hawaii International Conference on System Sciences.

Hanus, M. D., \& Fox, J. (2015). Assessing the effects of gamification in the classroom: A longitudinal study on intrinsic motivation, social comparison, satisfaction, effort, and academic performance. Computers \& Education, 80, 152-161.

Höllig, C. E, Tumasjan, A., \& Welpe, I.M. (2020). Individualizing gamified systems: The role of trait competitiveness and leaderboard design. Journal of Business Research, 106, 288- 303.

Huotari, K., \& Hamari, J. (2016). A definition for gamification: Anchoring gamification in the service marketing literature. Electronic Markets, 27(1), 21-31.

Hwang, G., Yang, L., \& Wang, S. (2013). A concept map-embedded educational computer game for improving students learning performance in natural science courses. Computers \& Education, 69, 121-130.

Kalogiannakis, M., Papadakis, S., \& Zourmpakis, A. I. (2021). Gamification in science education. A systematic review of the literature. Education Sciences, 11(1), 22.

Leedy, P. \& Ormrod, J. (2001). Practical research: Planning and design (7th ed.). Upper Saddle River, NJ: Merrill Prentice Hall. Thousand Oaks: SAGE Publications.

Majuri, J., Koivisto, J., \& Hamari, J. (2018). Gamification of education and learning: A review of empirical literature. In Proceedings of the 2 nd international GamiFIN conference, GamiFIN 2018. CEUR-WS.

Markopoulos, A. P., Fragkou, A., Kasidiaris, P. D., \& Davim, J. P. (2015). Gamification in engineering education and professional training. International Journal of Mechanical Engineering Education, 43(2), 118-131.

Maxwell, J. A. (2020). Qualitative research design: An interactive approach. Sage Publications.

McAuley, E., Duncan, T., \& Tammen, V. V. (1989). Psychometric properties of the intrinsic motivation inventory in a competitive sport setting: A confirmatory factor analysis. Research Quarterly for Exercise and Sport, 60(1), 48-58.

Mekler, E. D., Brühlmann, F., Tuch, A. N., \& Opwis, K. (2017). Towards understanding the effects of individual gamification elements on intrinsic motivation and performance. Computers in Human Behavior, 71, 525-534.

Pechenkina, E., Laurence, D., Oates, G., Eldridge, D., \& Hunter, D. (2017). Using a gamified mobile app to increase student engagement, retention and academic achievement. International Journal of Educational Technology in Higher Education, 14(1), 1-12. 
Piaget, J. (1929). The child's conception of the world (J. Tomlinson \& A. Tomlinson, Trans.). St. Albans: Granada.

Ryan, R. M. (1982). Control and information in the intrapersonal sphere: An extension of cognitive evaluation theory. Journal of Personality and Social Psychology, 43(3), 450.

Ryan, R. M., \& Deci, E. L. (2000). Intrinsic and extrinsic motivations: Classic definitions and new directions. Contemporary Educational Psychology, 25(1), 54-67.

Ryan, R. M., Mims, V., \& Koestner, R. (1983). Relation of reward contingency and interpersonal context to intrinsic motivation: A review and test using cognitive evaluation theory. Journal of Personality and Social Psychology, 45, 736-750.

Sánchez-Martín, J., Cañada-Cañada, F., \& DávilaAcedo, M. A. (2017). Just a game? Gamifying a general science class at university: Collaborative and competitive work implications. Thinking Skills and Creativity, 26, 51-59.

Saputra, A. D., Rahmatia, A., \& Wahyuningsih, S. H. (2021). Delivering gamification to overcome financial problems during a pandemic. Berkala Akuntansi dan Keuangan Indonesia, 6 (Edisi Spesial), 54-69.

Taherdoost, H. (2016). Sampling methods in research methodology; How to choose a sampling technique for research. SSRN Electronic Journal.

Williams, C. (2007). Research methods. Journal of Business \& Economics Research (JBER), 5(3), 65-71.

Yildirim, I. (2017). The effects if gamification-based teaching practices on student achievement and students' attitudes toward lessons. The Internet and Higher Education, 33, 86-92. 